\title{
The Note on Morphology of Rafflesia hasseltii Surigar from Bukit Tiga Puluh National Park, Riau
}

\author{
NERY SOFIYANTI ${ }^{1,2, \vartheta}$, KAMARUDIN MAT-SALLEH $^{2}$, DEDEK PURWANTO $^{1}$, EDY SYAHPUTRA $^{1}$ \\ ${ }^{1}$ Department of Biology, Faculty of Mathematics and Natural Sciences, University of Riau, Pekanbaru, Riau, Indonesia, 28293 \\ ${ }^{2}$ School of Environmental and Natural Resource Science, Biology Building $4^{\text {th }}$ floor, Room 4117 Faculty of Science and Technology, \\ National University of Malaysia, Bangi 46300, Selangor, Malaysia
}

Received: 17 Juli 2007. Accepted: 24 September 2007.

\begin{abstract}
The detail observation had been done on the morphological characters of Rafflesia hasseltii from Bukit Tiga Puluh National Park (BTNP). Currently, this endangered and rare flower found in two populations in this park, Aek Telap and Mandi Urau, Tanah Datar. The preliminary study on morphological characters of flowers from this site shows blotches and dot pattern variability. The detail observation of morphology of $R$. hasseltii from BTNP, presented the similarity to its type except the blotches pattern in perigone lobe. However, the further monitoring research is still needed to observe more flowers in this site. Due to its rarity, study on all Rafflesia species must be carefully done especially in using the characters of blotch for taxonomy evidence, as this characters show the variability among the flowers within population.
\end{abstract}

(c) 2007 Jurusan Biologi FMIPA UNS Surakarta

Key words: Rafflesia hasseltii, tjendawan muka rimau, morphology.

\section{INTRODUCTION}

Bukit Tiga Puluh is a hilly national park in Sumatra island. This park is located in two provinces, Riau and Jambi, owning a high diversity of plants and animals including endemic and endangered species. One of the well known plants from Bukit Tiga Puluh National Park (BTNP) is Rafflesia hasseltii Suringar. Being blessed with the unique white blotches on perigone lobe, this rare and extraordinary flower becomes the queen of the jungle. Local people know this plant as tjendawan muka rimau (tiger face mushroom) because the look of this blooming flower is more like tiger strips. This species also called tjendawan matahari (fungus solaris) (Suringar, 1879), tjendawan biring and Rafflesia merah putih (Zuhud et al., 1998). Suringar (1879) made the first description of this species based on the specimen from van Hasselt, who had collected the plant from Liki, Lompatan Anjing, West Sumatra. But this type locality had been gone due to plantation.

As well as other Rafflesia member, the comprehensive data including morphology of $R$. hasseltii in Bukit Tiga Puluh had been slow to accumulate. Commonly, it is due to the rarity of this plant. There are some factors that affect its endangered occurrence, (i) parasitic way of life, all Rafflesia species is entirely depend on its specific host (Tetrastigma) (Barkman et al., 2004; Latiff and Mat-Salleh, 1991); (ii) dioeciously flower (Meiyer, 1997), male and female flower occur in different individual; (iii) high mortality, more than $60-90 \%$ bud can not finish its life cycle (Nais, 2004); (iv) the percentage of female flower is lower than male, about $9 \%$ (Nais, 2001), and many female flowers fail to set fruit
(Emmons et al., 1991); (v) the development from seed to seed is about 3-4.5 years (Meiyer, 1997). Therefore, much of the natural history and biology of this genus remains a mystery.

In our observation of $R$. hasseltii complex in peninsular Malaysia, Sarawak (East Malaysia) and Sumatra (Indonesia), the bloom flowers were rarely found. Generally, in one population only two to five flowers were found in a year of study. In taxonomy study, the lack of specimen will make the interpretation of a taxon is difficult. In BTNP, other obstacle in conducting research on $R$. hasseltii was field observation due to its though location. To reach its population, a three-day walk was needed from the main path. Therefore, even though had been recorded almost 10 years in this park but does not pose complete information on its morphology. Whereas, this character is the simplest and common evidence, that have been widely used in taxonomy. Recently, there is no published paper on $R$. hasseltii from BTNP. In our knowledge, the most recent studies on this plant were conducted by Purwanto (2004) and Shahputra (2004), a preliminary study of its morphology and ecology.

As a holoparasitic plant, the morphological characters of $R$. hasseltii are very limited due to the lack of root, stem and leaf. The only visible part of this plant is vegetative part; therefore the detail description of its flower is compulsory for taxonomic evidence. Moreover this species had been misplaced many times in peninsular Malaysia. This study was conducted to examine the detail morphological characters of $R$. hasseltii as the common taxonomy evidence.

\section{MATERIAL AND METHOD}

\footnotetext{
- Corresponding address:

Jl. Raya Bangkinang Km 12,5, Pekanbaru 28293

Tel. \& Fax.: +62-761-63273

e-mail: sophie_yanti@yahoo.com
}

The study was conducted in two population of $R$. hasseltii from BTNP. Due to the difficulty in monitoring the 
site in BTNP, no fresh bloom flower was found during this study, except almost rotten that still could be observed its morphological characters. In order to maintains the life cycle of this species, only one specimen taken from each population. The picture that had been taken from this site by BTNP staff and visitor were also examined, to know the morphological variability. The morphological characters that calculated by use of Digitizer were, blotches coverage (BC) and density (BD) on perigone lobe and the ratio of aperture to diaphragm area (RAD) (see the formula for detail). Those three characters, together with number of dots on diaphragm and flower diameter were examined from 10 flowers of $R$. hasseltii from BTNP and it allies (flowers from Kerinci Seblat National Park (KSNP) Bengkulu, HPH Jambi (HPHJ), Tanjung Datu Sarawak, East Malaysia (TDSM) and peninsular Malaysia, in where this species had been recorded. The original illustration of this species also been studied. The area of blotches, aperture, diaphragm and size measurement were taken as explained in Figure 1. The blotches coverage and density were calculated from five perigone lobes (except where otherwise mentioned). The inner morphology was also observed based on the mature bud.

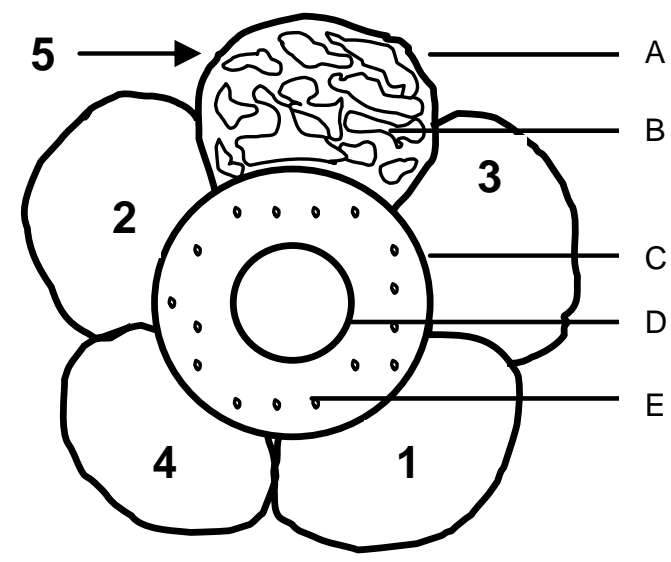

Figure 1. Morphological measurement, 1-5 are perigone lobe number based on their opening sequence. A. perigone lobe, B. blotch, C. diaphragm, D. aperture area, E. dot.

$B C$ (blotches coverage) $=\frac{\sqrt{\frac{\mathrm{AB} 1}{\mathrm{APL1}}+\frac{\mathrm{AB} 2}{\mathrm{APL2} 2}+\frac{\mathrm{AB} 3}{\mathrm{APL3}}+\frac{\mathrm{AB} 4}{\mathrm{APL4}}+\frac{\mathrm{AB} 5}{\mathrm{APL5}}}}{5} \times 100 \%$

$\mathrm{BD}$ (blotches density) $=\frac{\mathrm{NB} 1+\mathrm{NB} 2+\mathrm{NB} 3+\mathrm{NB} 4+\mathrm{NB} 5}{5}$

$\mathrm{RAD}$ (ratio aperture to diaphragm) $=1:(\mathrm{AD} / \mathrm{AA})$

Note: $A B=$ area of blotches, $A P=$ area of perigone lobe, $N B=$ number of blotches, $A D=$ area of diaphragm, $A A=$ area of aperture.

\section{RESULT AND DISSCUSSION}

\section{Morphology development}

Two populations were observed during the study. The first site was recovered in Aek Telap, half an hour walk from the old WWF camp, Datai Atas. This population had been recorded in 1999, while the second population in Mand Urau, was firstly recorded in 2004 , based on the information from Talang Mamak people. The life cycle of Rafflesia is consists of eight stages (Figure 2) (Nais, 2004).

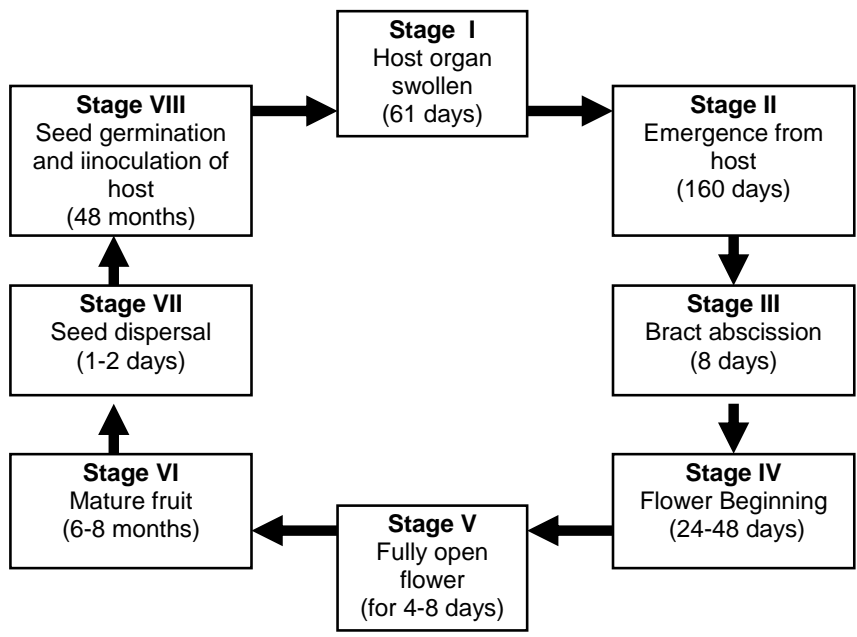

Figure 2. Life cycle of Rafflesia (redrawn from Nais (2004) by N. Sofiyanti).

Figure 3 presents the morphology development of $R$. hasseltii from BNTP. As many as 18 buds, together with three rotten flowers, were found in our first visit to Aek Telap. The buds found were in different stages; with the diameter is range from $2.5-17 \mathrm{~cm}$. The early stage of Rafflesia flower is cupula (about $1.5 \mathrm{~cm}$ in diameter), a young bud with the whitish bract. It will develop to bud that fully covered by black bract $(2-10 \mathrm{~cm})$ (Figure $3 a-c)$. Figure $3 c$ shows the early stage of perigone lobes presence $(10-12 \mathrm{~cm})$. The mature bud can be known by the abscission of bract and present a reddish orange perigone lobes (Figure $3 d$ ); the diameter of this bud is about $16-18 \mathrm{~cm}$. The bud enlargement of $R$. hasseltii from $0.5-18 \mathrm{~cm}$ diameters requires about 280 days (Nais, 2001). Further more He explained that Rafflesia will bloom for 4-8 days before decay (Figure $3 e, f$ ). The rotten flower will change to black (Figure $3 g, h$ ).

\section{Flower morphology}

It is commonly known that Rafflesia bloom is rarely found. Therefore the morphological observation is not as simple as other plant. In this study, we examined the mature bud and flower (more than 7 days bloom), as the lack of bloom flower found.

\section{Perigone lobe}

As well as other Rafflesia species, $R$. hasseltii in BTNP has five perigone lobes. It was previously reported that Rafflesia with six perigone lobe was found in peninsular Malaysia. But this phenomenon is rarely found and can not be used for identification. In all Rafflesia, the measurement of flower diameter should be done at least twice, due to uneven of perigone lobes area. For $R$. hasseltii, the diameter is 39.2$41 \mathrm{~cm}$. It was measured from perigone 1 (widest) to 5 and 2 to 3 (see Figure 1 for the number of perigone lobe, the numbering is based on the sequence of perigone lobe opening). The outer perigone that firstly open will be the largest. While the last opened perigone lobe will be the smallest. The range of its length is $10-12 \mathrm{~cm}$, and width is 11$14 \mathrm{~cm}$. Not like outer surface that smooth and has no pattern, the inner surface of perigone lobe has a unique blotches pattern. This surface was completely seen when the flower bloom. The blotch pattern may distinguish this taxon from other Rafflesia species. Figure 4 presents 


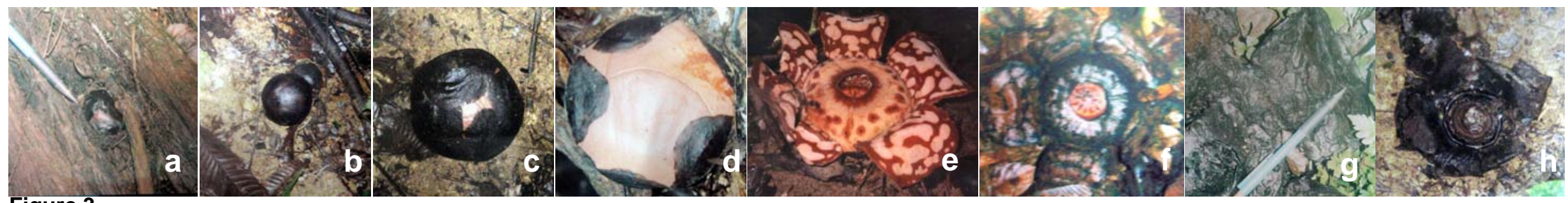

Figure 3.
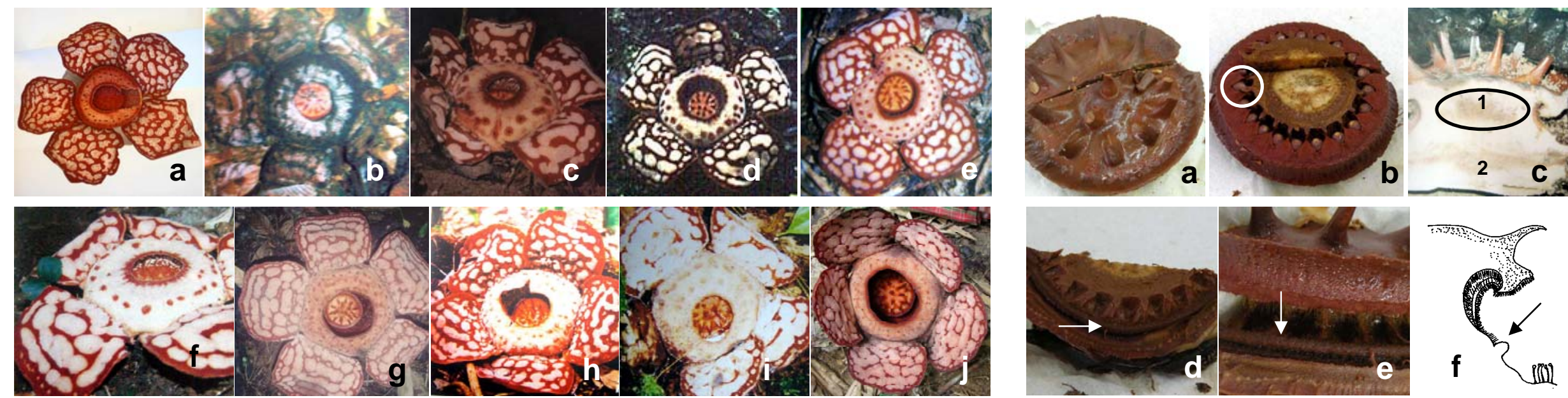

Figure 4.
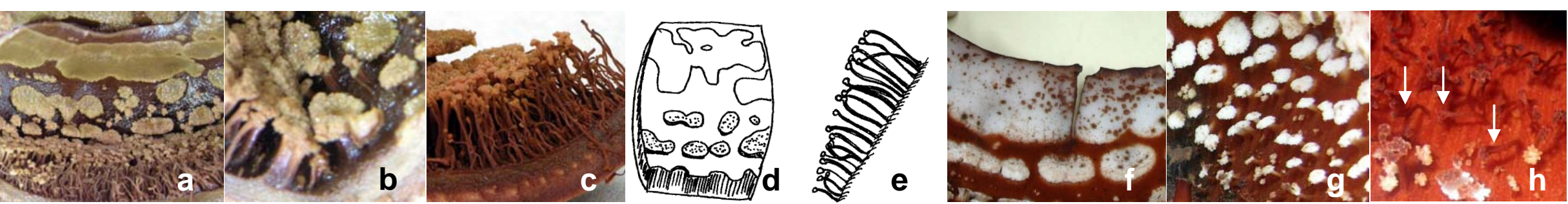

\section{Figure 5.}

Figure 3. The morphology development of $R$. hasseltii in BTNP: a. infected stem, b. bud fully covered by bractea, c. early stage of perigone lobe presence, d. almost mature bud, shows the outer surface of perigone lobes, e. blooming flower ${ }^{1}$, f. blooming flower (more than seven days), g.h. rotten flower.

Figure 4. Flower morphology of $R$. Hasseltii: a. Photographed from the original description of $R$. hasseltii (Veth, 1884) courtesy of Siti Munirah, b-c from BTNP Riau; b. flower found in this study, c. courtesy of Haryono, d. anonym (2007), e-f. flower from HPH Jambi, rephotographed from Zuhud et al. (1998), g. From KSNP (courtesy of Dr. Agus Susatya), h-i. Flower from Tanjung Datu, Sarawak (Ong, 2004), j. flower from Lebay, Perak, Malaysia ( $R$. azlanii, that previously identified as $R$. hasseltii).

Figure 5. Flower morphology of $R$. Hasseltii: a-c. Inner morphology of $R$. hasseltii from BTNP: a. window pattern, b. toadstool, c. ramenta; d-e. redrawn by Nery Sofiyanti from Veth (1884), d. window pattern, e. ramenta, f-g. Rafflesia from Peninsular Malaysia (identified as $R$. azlanii), f. window pattern, g. toadstool, h. ramenta (show the branched ramenta, marked by arrow).

Figure 6. Female and male flower of R. hasseltii BTNP: a. upper surface of disc, with processus, b. lower surface of disk, with anthers arranged in cycle, c. Vertical section of female flower, show thousands ovul (1) in the middle of ovary (2), d-e. annulus (arrow), f. Redrwan by Nery Sofiyanti from Veth (1884), showing single annulus (arrow). 
Table 1. Morphological characters of $R$. hasseltii and its allies.

\begin{tabular}{lllllll}
\hline Code & $\begin{array}{c}\text { DM } \\
(\mathbf{c m})\end{array}$ & BC (\%) & BD & NO & RAD & Figure 4 \\
& & & & & \\
\hline MLAP & $56-59$ & 41.32 & 32 & \pm 49 & $1: 5$ & $\mathrm{a}$ \\
BNTP 1 & $33-35$ & 60.15 & 2 & 30 & $1: 7$ & $\mathrm{~b}$ \\
BNTP 2 & $\mathrm{Na}$ & $56.23^{*}$ & 5 & $\mathrm{Na}$ & $\mathrm{Na}$ & Not presented \\
BNTP 4 & $\mathrm{Na}$ & 46.23 & 17 & 26 & $1: 10$ & $\mathrm{~d}$ \\
BNTP 3 & $\mathrm{Na}$ & 53.35 & 9 & 25 & $1: 4$ & $\mathrm{C}$ \\
HPHJ 1 & $\star *$ & 44 & 22 & 45 & $1: 5$ & $\mathrm{e}$ \\
HPHJ 2 & $* *$ & 63 & 8 & 27 & $1: 8$ & $\mathrm{f}$ \\
KSNP 1 & $52-59$ & 58 & 16 & 56 & $1: 4$ & $\mathrm{~g}$ \\
TDSM 1 & $* * *$ & 43.3 & 21 & 63 & $1: 6.5$ & $\mathrm{~h}$ \\
TDSM 2 & $\star * *$ & 73.26 & 2 & 25 & $1: 6$ & $\mathrm{i}$ \\
ULPM & $28-31$ & 65.75 & 13.5 & 37 & $1: 4$ & $\mathrm{j}$
\end{tabular}

Note: * based on one perigone lobe, ${ }^{\star \star} 35-50 \mathrm{~cm}$ (Zuhud et al., 1998), $42-53$ $\mathrm{cm}$ (Ong, 2004). ULPM = Ulu Lebay, Peninsular Malaysia. For more abbreviation see text.

the flowers morphology of $R$. hasseltii. Four morphological characters had been examined from all flowers in Figure 4, and presented in Table 1.

The diameter of flower found during this study is smaller than the type that reaches up to $56-59 \mathrm{~cm}$. The smaller flower size of $R$. hasseltii mentioned in Koorder (1917) was $43 \mathrm{~cm}$. But the BC and BD value of $R$. hasseltii from BTNP, Riau shows variability, the $B C$ range from $46.3-60.15 \mathrm{~cm}$, while BD 2 to 19. This variability also found within KSNP and TD population. Therefore, the observation of those characters must be carefully done. This species was misplaced many times in peninsular Malaysia, commonly due to the variability of blotch pattern. Figure $4 i$ is the flower from Ulu Lebay, Perak, peninsular Malaysia, currently identified as $R$. azlanii Latiff et Wong (Latiff and Wong, 2004). This species had been previously recorded as $R$. hasseltii.

The $\mathrm{BC}$ value indicates the area of blotches on perigone lobes. The higher of $\mathrm{BC}$ value, the wider is the blotches area is. While $B D$ value indicates the density of blotches. The value of $B D$, together with $B C$, will represent the blotches pattern. In this study, R. hasseltii has BC $60.15 \%$ but low BD value, 2. It's indicates the blotches pattern is not well spaced, but connected to each other. The original illustration, show a well spaced pattern. As seen in Figure 1, picture taken before this study had lower BC value, 46.32$47.2 \%$. It's more similar to its original illustration.

The blotches pattern in $\mathrm{HPH}$ Jambi had been contrastly found (Figure 4e and f) within the population. Based on the characters observed, Figure $4 \mathrm{e}$ has the highest similarity with the original illustration. It blotches are well spaced, while the flower found in the same population showed a connected blotches (Figure 4f). In KSNP, Bengkulu, the blotches pattern from six flowers within the population is almost similar. It has elongated blotches, with the $\mathrm{BC} 45-58 \%$. Figure $4 \mathrm{~g}$ is the flower with the highest $\mathrm{BC}$ from this population. The outer morphology of this flower is quite different from other Sumatran population.
Its dot pattern is look like the flower from Malaysia. Flower from Malaysia (Figure 4h, i, j) distinguished from BTNP and $\mathrm{HPHJ}$ population, especially on dot pattern on diaphragm. All flowers from Sumatra (except from KSNP) had clear red dot, even though the number were different among them, while flower from Malaysia had the faint dots.

\section{Aperture and diaphragm}

Aperture is the opening area in the middle of perigone tube, while diaphragm is the upper part of perigone tube. $R$. hasseltii has a rounded aperture $(5-7 \mathrm{~cm}$ in wide) and most of the diaphragm (4-7 cm in wide) is pentagonal, except a flower from HPH Jambi (Figure 4e). For certain species, these characters can be used to distinguish from other Rafflesia species. The smallest aperture belongs to $R$. microphylora (about $1.5 \mathrm{~cm}$ ), and become the characteristic of this species. While $R$. manillana has the widest aperture and the smallest diaphragm. In this study, the ratio of aperture to diaphragm is range from 1: 4 to $1: 10$.

\section{Inner morphology}

The inner morphology of Rafflesia is the morphology inside the perigone tube. Figure 7 presents the vertical section of Rafflesia flower. Window is the upper part of perigone tube, located under the diaphragm. In $R$. hasseltii, window pattern consist of two different parts, wide and continuous white blotches on the upper and well spaced blotches on the lower part (Figure 5a). Under the window, there is a structure called toadstool. This structure is the transformation form to ramenta. In this study, toadstool is $0.4-1.2 \mathrm{~cm}$, white, like mushroom shape and the tip is unbranched (Figure 5b.). The lowest part in perigone tube is ramenta, with white color of tip (Figure $5 \mathrm{c}$ ). It is a slender structure with capitate tip, $0.9-1.1 \mathrm{~cm}$ in length. Both toadstool and ramenta were densely found. Based on our observation, the window pattern and ramenta of $R$. hasseltii in BTNP are similar to the type (Figure $5 \mathrm{~d}$ and e). $R$. azlanii from peninsular Malaysia is a species that previously identified as $R$. hasseltii. It shows the different window pattern and ramenta, but the toadstool shape is similar even though they stand more loosely (Figure $5 \mathrm{~g}$ ). The upper blotches on window of $R$. azlanii was started from the edge of aperture (Figure 5f), white ramenta were branched with capitate tip (Figure $5 \mathrm{~h}$ ).

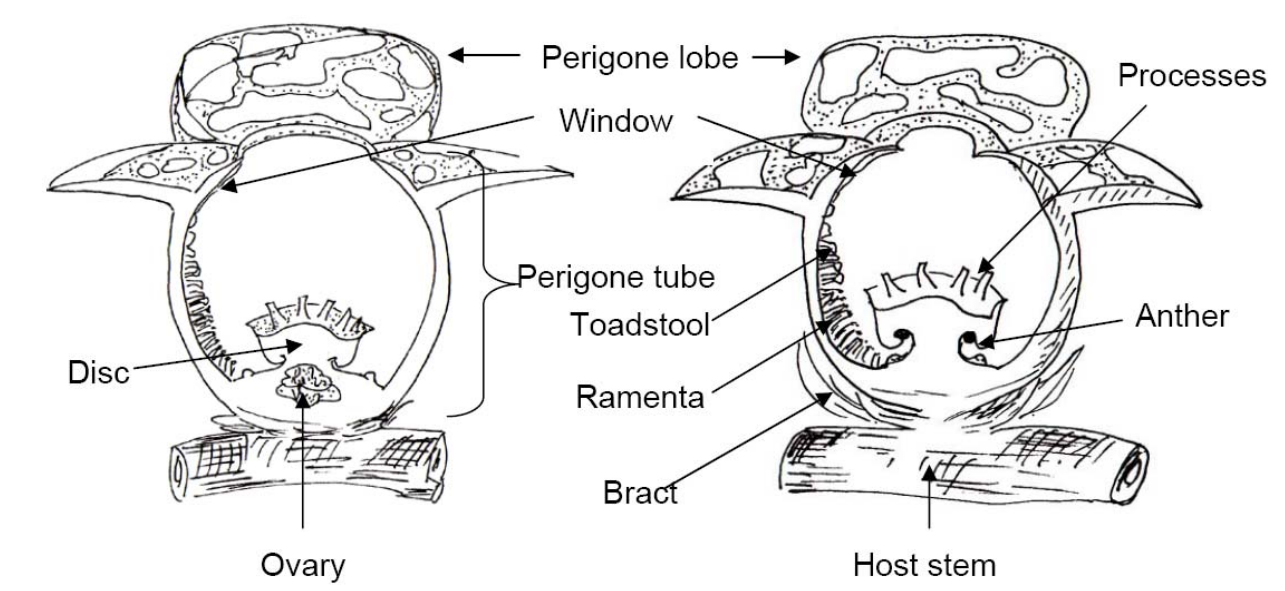

Figure 7. The vertical section of $R$. hasseltii, a. female flower, b. male flower (Drawn by N. Sofiyanti). 
Disc of Rafflesia is located in the middle of perigone tube (Figure 6a). The diameter is about $10 \mathrm{~cm}$. Processes can be found on the upper surface of disc, $1.8-2 \mathrm{~cm}$ in height. The basal area of processes is wider than the tip. $R$. hasseltii has 13-17 processes, $1.5-1.7 \mathrm{~cm}$ in height. In this study, we observed female and male flower. The male bud or flower have anthers (Figure 6b), normally surrounded by fine bristle (Nais, 2000) while female flower lacks both. We found 20 anthers in male flower of the taxa studied. In female flower, ovary found under the disk (Figure 6c). The annulus is one of he important characters in Rafflesia. It is a concave cycle surrounding the bottom of disk. $R$. hasseltii has one annulus (Figure $6 \mathrm{~d}-\mathrm{f}$ ).

Based on the discussion of morphological characters above, following is the description of $R$. hasseltii from BTNP: Mature bud: $16-18 \mathrm{~cm}$. Flower diameters: $33-35 \mathrm{~cm}$. Perigone lobes: $10-12 \mathrm{~cm}$ long and $11-14 \mathrm{~cm}$ wide, bright red brick. Blotches: coverage 46.23-60.15\%, density 2-12, whitish in color. Aperture: rounded, $5-7 \mathrm{~cm}$ wide; ratio to diaphragm 1: 4 to 1: 10. Diaphragm: mostly pentagonal, 4-7 $\mathrm{cm}$ wide. Dot on diaphragm: rounded, sometime elongated, 21-30, bright red and clearly present. Window: wide and whitish blotches near the rim. Toadstool: 4-12 mm, white, unbranched, downward gradually become ramenta. Ramenta: white, 9-1.3 mm, linear, unbranched, densely found in perigone tube Disc: $10-13 \mathrm{~cm}$. Processes: 13-17, 1.5-1.7 cm high, not flattened, styliform. Anther: 20.

\section{CONCLUSION}

The detail observation of morphology of $R$. hasseltii from BTNP, presented the similarity to its type except the blotches pattern in perigone lobe. However, the further monitoring research is still needed to observe more flowers in this site. Due to its rarity, study on all Rafflesia species must be carefully done especially in using the characters of blotch for taxonomy evidence, as this characters show the variability among the flowers within population.

\section{ACKNOWLEDGEMENT}

The authors are grateful to Haryono, the head of Bukit Tiga Puluh National Park, for his collaboration, all staff of BTNP, especially to Lancar and Katak for their guidance during the field trip. Also thank to Minister of Forestry, Indonesia for the permit to conduct the research.

\section{REFFERENCE}

Barkman, T.J., S.H. Lim, K. Mat-Salleh, and J. Nais. 2004. Mitohondrial DNA sequences reveal the photosynthetic relative on Rafflesia, the world's largest flower. PNAS. 1001 (3): 787-792.

Emmons, L.H., J. Nais, and A. Briun. 1991. The fruit and consumers of Rafflesia keithii (Rafflesiaceae). Biotropica 23 (2): 197-199.

Koorder, S.H. 1917. Notiz über eine neue abbildung von Rafflesia hasseltii Sur.

Latiff, A and K. Mat-Salleh. 1991. Rafflesia. In: Kew, R. (ed.). The State of Nature Conservation in Malaysia. Kuala Lumpur: Malayan Nature Society-International Development and Research Centre of Canada.

Latiff, A. and M. Wong. 2003. A new species of Rafflesia from peninsular Malaysia. Folia Malaysiana 4: 135-146.

Meiyer, W. 1997. Rafflesiaceae. Flora Malesiana. Series I Vol 13: 1-42.

Nais, J. 2001. Rafflesia of the World. Kota Kinabalu: Sabah Park.

Nais, J. 2004. Rafflesia Bunga Terbesar di Dunia. Kuala Lumpur: Dewan Bahasa dan Pustaka.

Ong, L.P. 2004. Biologi Rafflesia hasseltii Tanjung Datu, Sarawak. [Thesis] Bangi: Pusat Studi Sains Sekitaran dan Sumber Alam, Fakulti Sains dan Teknologi, Universiti Kebangasaan Malaysia.

Purwanto, D., 2004. Perkembangan Morphologi Bunga Rafflesia hasseltii Suringar di Aek Telap, Tanah Datar Taman Nasional Bukit Tiga Puluh, Riau. [Thesis]: Pekanbaru: Jurusan Biologi FMIPA, Universitas Riau.

Suringar, F.W.R., 1879. Rafflesia hasseltii. Acta Societatis Regiae Scientiarum Neerlandicae. 1-3

Syahputra, E., 2004. Vegetasi di sekitar Rafflesia hasseltii Suringar di Aek Telap, Tanah Datar Taman Nasional Bukit Tiga Puluh, Riau. [Thesis]: Pekanbaru: Jurusan Biologi FMIPA, Universitas Riau.

Zuhud, E.A.M, A. Hikmat, and N. Jamil. 1998. Rafflesia Indonesia, Keanekaragaman, Ekologi dan Pelestariannya. Bogor: Yayasan Pembinaan Suaka Alam dan Suaka Margasatwa Indonesia (The Indonesia Wildlife Foundation) dan Laboratorium Konservasi Tumbuhan, Institut Pertanian Bogor. 